\title{
Nevrofibromatose type 2 og auditorisk hjernestammeimplantat
}

\author{
Sammendrag \\ Bakgrunn. Nevrofibromatose type 2 \\ er en sjelden og alvorlig, arvelig svulst- \\ sykdom som skyldes mutasjon i et \\ tumorsuppressorgen. Vi vil med denne \\ artikkelen gi en oversikt over lidelsen \\ og omtale behandling med auditorisk \\ hjernestammeimplantat.
}

Materiale og metode. Denne oversikten er basert på forfatternes egne erfaringer med sykdommen og litteratur fremskaffet ved ikke-systematiske søk i PubMed.

Resultater. Nevrofibromatose type 2 skyldes bortfall av normal funksjon til tumorsuppressorproteinet merlin. Normalt merlin undertrykker cellevekst og celledeling. Det kliniske bildet domineres av nevrologiske symptomer og tegn som skyldes utvikling av multiple svulster, hovedsakelig schwannomer og meningeomer. Bilateralt vestibularisschwannom er patognomonisk for sykdommen. Progredierende hørselstap er vanligste symptom ved debut i voksen alder. Presenil katarakt, øyemotilitetsforstyrrelser, perifer nevropati og hudsvulster forekommer hyppig. De fleste personer med nevrofibromatose type 2 vil bli døve. Mange utvikler en betydelig invaliditet, og forventet livslengde er kortere enn hos friske. Målet for dagens behandling er å minimere funksjonstap og opprettholde livskvalitet. Et auditorisk hjernestammeimplantat stimulerer de sentrale hørselsbanene og kan gi deler av hørselen tilbake ved døvhet.

Fortolkning. Tverrfaglig og sentralisert behandling er nødvendig. Dette øker livslengde og bedrer resultatet etter kirurgi. Auditorisk hjernestammeimplantat er en viktig del av denne pasientgruppens hørselsrehabilitering. Ny kunnskap om sykdomsmekanismene gir håp om fremtidig molekylært rettet behandling.

\section{Torbjørn Elvsåshagen}

torbjorn.elvsashagen@rikshospitalet.no Avdeling for nevropsykiatri og psykosomatisk medisin

Nevroklinikken

Oslo universitetssykehus, Rikshospitalet 0027 Oslo

og

Institutt for psykiatri

Det medisinske fakultet

Universitetet i Oslo

\section{Volker Solyga}

Nevrologisk avdeling

Nevroklinikken

\section{Søren Jacob Bakke}

Nevroradiologisk seksjon

Bilde- og intervensjonsklinikken

\section{Arvid Heiberg}

Avdeling for medisinsk genetikk

Oslo universitetssykehus, Rikshospitalet

\section{Emilia Kerty}

Nevrologisk avdeling

Nevroklinikken

Oslo universitetssykehus, Rikshospitalet og

Det medisinske fakultet

Universitetet i Oslo

Nevrofibromatosene er en gruppe arvelige nevrokutane sykdommer kjennetegnet av multiple svulster som hovedsakelig utgår fra perifere nerver. Man kjenner i dag tre ulike former for nevrofibromatose: nevrofibromatose type 1 (NF1), nevrofibromatose type 2 (NF2) og schwannomatose. Ved nevrofibromatose type 1 , som tidligere ble kalt von Recklinghausens sykdom, ses café-au-laitflekker, perifere nevrofibromer og fregner i aksiller og lysker. Prevalensen er om lag 1 per 4000 og skyldes inaktivering av tumorsuppressorgenet NF1 på kromosom 17 (1).

Nevrofibromatose type 2 er en sjelden og alvorlig, arvelig sykdom der mutasjoner i et tumorsuppressorgen på kromosom 22 gir utvikling av schwannomer (ramme 1) og andre svulster $\mathrm{i}$ nervesystemet. Bilateralt vestibularisschwannom er patognomonisk for nevrofibromatose type $2 \mathrm{og}$ utvikles hos om lag $95 \%$ av pasientene. Schwannomatose er den tredje formen for nevrofibromatose som først nylig ble adskilt fra nevrofibromatose type 2 som en egen sykdom. Dens molekylære årsak er ikke fullstendig kartlagt. Ved schwannomatose ses multiple schwannomer, men ikke vestibularisschwannom.

Vi vil med denne artikkelen gi en oversikt over nevrofibromatose type $2 \mathrm{og}$ omtale behandling med auditorisk hjernestammeimplantat.

\section{Materiale og metode}

Denne oversikten er basert på forfatternes egne erfaringer med sykdommen og litteratur fremskaffet ved ikke-systematiske søk i PubMed.

\section{Forekomst}

Fødselsinsidensen av nevrofibromatose type 2 er estimert til om lag 1 per 25000 (2). Prevalensen ble i 1992 beregnet til 1 av 210000 i en engelsk studie (3). Den samme forskergruppen fant i 2005 en prevalens på 1 av 100000 (2). En slik økning av prevalensen kan skyldes bedret diagnostikk og behandling av tilstanden (2). I Norge kjenner man per 2008 om lag 20 personer med sykdommen.

\section{Genetikk og patofysiologi}

Arvegangen ved nevrofibromatose type 2 er autosomalt dominant. I familier med sykdommen i flere generasjoner er sannsynligheten for at neste generasjon arver sykdommen $50 \%$ (4). Penetransen er nær $100 \%$, ettersom nærmest alle med medfødt mutasjon i NF2-genet utvikler sykdommen før fylte 60 år (3).

Om lag halvparten av personer med nevrofibromatose type 2 arver sin genfeil fra en rammet forelder, mens i resten av tilfellene skyldes sykdommen en nyoppstått mutasjon (3). Nye mutasjoner kan oppstå i en kjønnscelle fra mor eller far eller i celler etter befruktning. En mutasjon som oppstår etter befruktning, kan gi en såkalt mosaikkform av nevrofibromatose type 2 . Dette innebærer at ikke alle kroppens celler inneholder mutasjonen, men kun etterfølgere til den muterte cellen (5). Om lag 30\% av pasienter med

\section{Hovedbudskap}

- Nevrofibromatose type 2 er en alvorlig. arvelig svulstsykdom som skyldes mutasjon i et tumorsuppressorgen

- Dette fører til utvikling av multiple svulster i nervesystemet, og bilateralt vestibularisschwannom er patognomonisk

- Auditorisk hjernestammeimplantat er en viktig del av behandlingen

- Ny kunnskap om sykdomsmekanismene gir håp om fremtidig molekylært rettet terapi 


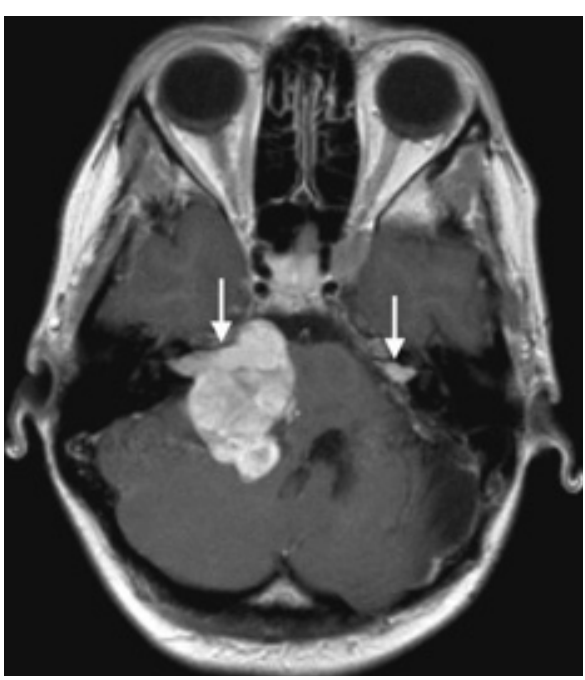

Figur 1 Aksialt T1-vektet MR-bilde med kontrast viser bilateralt vestibularisschwannom (piler)

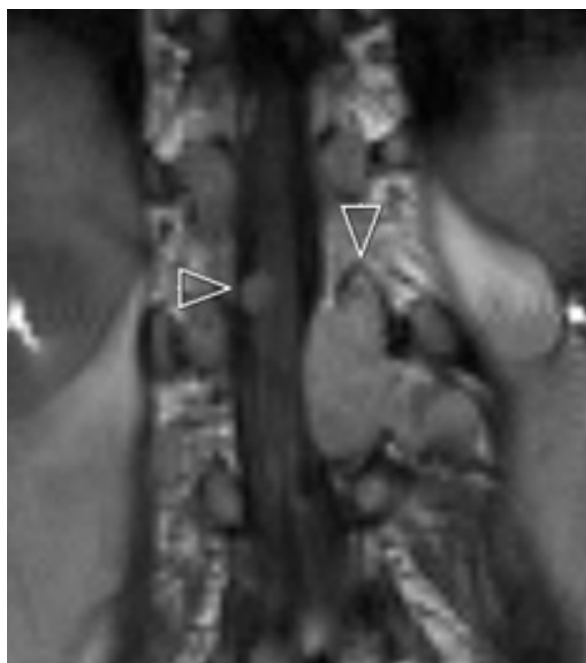

Figur 2 Sagittalt T1-vektet MR-bilde med kontrast viser sannsynlige schwannomer i spinalkanalen og i mellomvirvelhull (pilhoder)

nyoppstått nevrofibromatose type 2 har mosaikkformen (6). Ved mosaikkformen foreligger ofte et mildere klinisk bilde. Det kliniske bildet vil avhenge av på hvilket trinn $\mathrm{i}$ den embryologiske celledelingen mutasjonen inntraff og hvilke cellepopulasjoner som ble rammet. Inntreffer mutasjonen på et tidlig stadium, vil det kliniske bildet være som

\section{Ramme 1}

\section{Schwannom}

En schwannsk celle er en spesialisert gliacelle som omgir og elektrisk isolerer aksoner i perifere nerver. Et schwannom er en godartet, innkapslet svulst som består av schwannske celler. Et vestibularisschwannom er et schwannom som utgår fra vestibularisdelen av 8. hjernenerve. Dette ble tidligere kalt akustikusnevrinom ved en mutasjon i en kjønnscelle. En sen mutasjon derimot kan gi manifestasjoner i utelukkende én kroppshalvdel eller kun i ett segment av nervesystemet. Dersom et barn av en person med mosaikkformen arver mutasjonen, vil alle celler hos barnet inneholde mutert NF2-gen. Dette vil gi et alvorligere klinisk bilde hos barnet enn hos forelder. Sannsynligheten for at barn av personer med mosaikkform arver sykdommen er imidlertid mindre enn $50 \%$, erfaringsmessig $25-33 \%(6)$.

NF2-genet koder for tumorsuppressorproteinet merlin. Merlin tilhører en familie proteiner som kobler celleskjelettet til proteiner på cellens overflate (7). Merlin uttrykkes blant annet i schwannske celler, i meningeale celler, i perifere nerver og i øyets linse (1). Dyrestudier viser at inaktivering av NF2-genet gir økt vekst av schwannske og meningeale celler, utvikling av schwannomer og meningeomer og katarakt (7). Mekanismen bak merlins tumorsupprimerende effekt er ikke fullstendig kjent. Merlin stabiliserer sannsynligvis kontakten mellom naboceller og mellom celler og ekstracellulærsubstansen. Slike forbindelser har viktig betydning for undertrykkelse av cellevekst og celledeling (8). Forskningen tyder videre på at merlin regulerer overflatereseptorer for vekstfaktorer, som reseptortyrosinkinaser, og intracellulære signalveier med betydning for celleproliferasjon (7). Bortfall av normal merlinaktivitet vil dermed kunne gi ukontrollert cellevekst og svulstdanning. I tillegg til proteinets rolle ved nevrofibromatose type 2 har merlin sannsynligvis også betydning ved annen svulstutvikling. Blant annet er det påvist inaktivering av NF2-genet i de fleste sporadiske schwannomer og i om lag $60 \%$ av sporadiske meningeomer (8).

\section{Klinisk bilde}

Det kliniske bildet ved nevrofibromatose type 2 domineres av symptomer og tegn som skyldes utvikling av multiple svulster. Om lag $95 \%$ av personer med sykdommen vil utvikle bilateralt vestibularisschwannom (1), som vist i figur 1 . Hvorfor vestibularisdelen av 8. hjernenerve er predileksjonssted, er ikke kjent. Schwannomer på andre hjernenerver og på perifere nerver, intrakraniale og intraspinale meningeomer, ependymomer og lavgradige gliomer er andre svulster assosiert med sykdommen (4). Spinale svulster, som vist i figur 2, kan påvises hos $80-90 \%$ av personer med nevrofibromatose type 2 (4). Imidlertid vil kun om lag $30 \%$ av disse ha behov for spinal kirurgi (9).

Gjennomsnittlig alder ved symptomdebut ved nevrofibromatose type 2 var i en større studie 21,6 år (3). Hos majoriteten av personer med debut $i$ voksen alder er progredierende sensorinevralt hørselstap første symptom. Plutselig døvhet forekommer også. Andre vanlige symptomer ved debut er øresus, svimmelhet og balansevansker (3). Ved symptomdebut hos barn ses ofte et annet kli- nisk bilde. I et engelsk materiale fikk $18 \%$ av personer med nevrofibromatose type 2 symptomer før fylte 16 år (10). Her debuterte kun $43 \%$ av barna med symptomer som kunne tilskrives affeksjon av 8. hjernenerve. $19 \%$ hadde symptomer som krampeanfall og synsforstyrrelser sekundært til meningeom. Spinale svulster ga kraftsvikt og sensoriske utfall hos $11 \%$ ved debut (10). I en annen studie var ryggmargskompresjon og synsforstyrrelser som diplopi og katarakt hyppigste funn ved debut hos barn (11).

Øyeaffeksjon kan påvises hos om lag $80 \%$ av personer med nevrofibromatose type $2(4,12)$. Presenil katarakt, vanligvis bakre subkapsulær polstær, ses hos 60-80\%, men kirurgisk behandling er sjelden nødvendig (4). Epiretinale membraner, retinale hamartomer, optikusmeningeomer og optikusgliomer er andre øyefunn som er assosiert med nevrofibromatose type 2 (4, 12). For øvrig er hornhinneaffeksjon og øyemotilitetsforstyrrelser sekundært til svulstvekst og svulstbehandling hyppig forekommende. Ettersom de fleste av disse pasientene vil miste hørselen, er konsekvensen av synssvekkelse spesielt alvorlig.

I et arbeid fant man tegn til perifer nevropati hos 10 av 15 pasienter med nevrofibromatose type 2 (13). Svulstvekst med kompresjon av perifere nerver og cellulær dysfunksjon på grunn av endret merlinekspresjon er mulige årsaker til nevropatien. Denne kan gi progredierende nevrologiske utfall, uttalt muskulær atrofi og i enkelte tilfeller fatal utgang (4). Også mononevropatier kan forekomme. Hyppigst rammes 7. hjernenerve (9).

Hudsvulster ses hos om lag $70 \%$ av personer med nevrofibromatose type 2 , men i langt mindre antall enn ved type 1 (9). Den vanligste typen er en plakkliknende, behåret intrakutan lesjon, lett pigmentert og elevert. Om lag 40\% har café-au-lait-flekker, men svært sjelden ses seks eller flere flekker (3).

På tross av optimal håndtering vil de fleste personer med nevrofibromatose type 2 bli døve. Mange utvikler en betydelig invaliditet med balansevansker, synsforstyrrelser og kraftreduksjon. En vesentlig andel blir rullestolbrukere i tidlig voksen alder (4). Personer med sykdommen har kortere forventet livslengde enn friske. I et arbeid fant man at 40 \% var døde før fylte 50 år (3), og ved utbredt svulstutvikling dør mange i 20- og 30årene (4). Intrakraniale meningeomer er en vanlig dødsårsak.

\section{Diagnostikk}

Hvis flere enn to familiemedlemmer er rammet, vil genetisk diagnostikk ved blodprøve kunne avkrefte eller bekrefte NF2-mutasjon med over $95 \%$ sannsynlighet hos andre familiemedlemmer (9). Dersom man ikke finner mutasjon ved søk i blod, bør svulstvev undersøkes. Prenatal diagnostikk og preimplantasjonsdiagnostikk kan også være aktuelt i familier med nevrofibromatose type 2 . 
Om genetisk diagnostikk ikke er ønskelig eller mulig, bør personer som kan arve tilstanden, følges fra fødselen (9). Hudinspeksjon og oftalmologisk og nevrologisk undersøkelse bør gjøres årlig fra spedbarnsalder. Cerebral MR bør utføres annethvert år i alderen 10-20 år og hvert 3. år inntil fylte 40 år. Etter dette er risikoen for å utvikle tilstanden svært liten hos en asymptomatisk person. Det er ellers anbefalt å utføre MR av ryggsøylen hvert tredje år (9). For øvrig bør man mistenke nevrofibromatose type 2 ved ensidig vestibularisschwannom eller meningeom før fylte 30 år, ved multiple spinale svulster og ved kutane schwannomer (9).

Det er utarbeidet ulike sett av diagnostiske kriterier for nevrofibromatose type 2. Disse har høy spesifisitet. Derimot er sensitiviteten til de diagnostiske kriteriene lav i tidlig sykdomsfase, spesielt blant personer uten familiær nevrofibromatose type 2 som ikke debuterer med bilateralt vestibularisschwannom (14). Det er derfor behov for en revisjon av de diagnostiske kriteriene for å øke sensitiviteten i sykdommens tidlige fase. De såkalte Manchester-kriteriene (fig 3), har høyest sensitivitet og brukes i Norge i dag (14).

Schwannomatose er en differensialdiagnose til nevrofibromatose type 2, og dens diagnostiske kriterier er vist i figur 4 . Forekomsten av schwannomatose er ikke fullstendig kartlagt, men tilstanden kan være like hyppig forekommende som nevrofibromatose type 2 . Tilfellene er vanligvis sporadiske, men det er også beskrevet autosomalt dominant arvegang (15). Ved schwannomatose ses to eller flere schwannomer i relasjon til perifere nerver, men ikke vestibularisschwannomer (16). Det er sannsynligvis ingen økt forekomst av intrakraniale svulster eller hudsvulster (15). Det viktigste symptomet ved schwannomatose er smerter, som skyldes schwannomer lokalisert til perifere nerver. Nevrologiske utfall er sjeldnere ved schwannomatose enn ved nevrofibromatose type 2, og forventet livslengde er sannsynligvis ikke redusert (16).

\section{Oppfølging og behandling}

Oppfølging og behandling av nevrofibromatose type 2 er komplekst og krever en tverrfaglig tilnærming. Pasientene bør følges av blant annet nevrolog, nevrokirurg, øre-nesehals-lege, øyelege, genetiker, fysioterapeut og sykepleier. Det overordnede ansvaret for dem bør sentraliseres, slik at nødvendig kompetanse og adekvat behandling sikres (9). Sentralisert behandling reduserer sykdommens dødelighet og bedrer resultatet av kirurgisk intervensjon sammenliknet med ikke-sentralisert behandling (17). I Norge følges mange av disse pasientene ved Rikshospitalet.

Kurativ behandling finnes ikke per i dag. Målet for dagens behandling er å minimere funksjonstap og opprettholde livskvalitet gjennom lokal svulstkontroll. Alternativene ved svulstrettet behandling er kirurgi og
Figur 3 Diagnostiske kriterier for nevrofibromatose type 2 (Manchester-kriteriene) (14). Diagnosen settes når ett eller flere av kriteriene A-D er oppfylt

\begin{tabular}{|c|l|}
\hline A & Bilateralt vestibularisschwannom \\
\hline B & $\begin{array}{l}\text { Førstegradsslektning med nevrofibromatose type } 2 \text { og unilateralt } \\
\text { vestibularisschwannom eller minst to av' }: \text { meningeom, gliom, } \\
\text { nevrofibrom, schwannom, bakre subkapsulær polstær }\end{array}$ \\
\hline C & $\begin{array}{l}\text { Unilateralt vestibularisschwannom og minst to av' } \\
\text { meningeom, gliom, nevrofibrom, schwannom, bakre subkapsulær } \\
\text { polstær }\end{array}$ \\
\hline D & $\begin{array}{l}\text { Multiple meningeomer (to eller flere) og unilateralt } \\
\text { vestibularisschwannom eller minst to av' }: \text { gliom, nevrofibrom, } \\
\text { schwannom, bakre subkapsulær polstær }\end{array}$ \\
\hline
\end{tabular}

'Med "to av" menes individuelle svulster, uavhengig av svulsttype, eller polstær stereotaktisk strålekirurgi (gammaknivbehandling). Cellegiftbehandling benyttes ikke. Ønsket om å bevare funksjon ved avlastende kirurgi må veies mot den betydelige faren for iatrogen skade. Som en hovedregel anbefales konservativ behandling for svulster som er klinisk og radiologisk stabile.

Håndteringen av vestibularisschwanno-
Figur 4 Reviderte diagnostiske kriterier for schwannomatose (1). Det er en forutsetning for diagnose at man ikke oppfyller diagnostiske kriterier for nevrofibromatose type 2 eller har følgende: a) tegn til vestibularisschwannom ved MR-undersøkelse, b) medfødt NF2-mutasjon eller cl førstegradsslektning med nevrofibromatose type 2. Diagnose settes når ett eller flere av kriteriene er oppfylt

\begin{tabular}{|l|c|l|}
\hline $\begin{array}{l}\text { Sikker } \\
\text { schwannomatose }\end{array}$ & A & $\begin{array}{l}\text { Alder > 30 år og to eller flere ikke-intradermale } \\
\text { schwannomer (minst ett bekreftet ved } \\
\text { histologisk undersøkelse) }\end{array}$ \\
\cline { 2 - 3 } & B & $\begin{array}{l}\text { Ett histologisk bekreftet schwannom og } \\
\text { førstegradsslektning som oppfyller ovenstående } \\
\text { kriterier }\end{array}$ \\
\hline \multirow{2}{*}{$\begin{array}{l}\text { Mulig } \\
\text { schwannomatose }\end{array}$} & A & $\begin{array}{l}\text { Alder <30 år og to eller flere ikke-intradermale } \\
\text { schwannomer (minst ett bekreftet ved } \\
\text { histologisk undersøkelse) }\end{array}$ \\
\cline { 2 - 4 } & B & $\begin{array}{l}\text { Alder > 45 år og ingen symptomer på affeksjon } \\
\text { av 8. hjernenerve og to eller flere } \\
\text { ikke-intradermale schwannomer (minst ett } \\
\text { bekreftet ved histologisk undersøkelse) }\end{array}$ \\
\hline & C & $\begin{array}{l}\text { Radiologiske tegn til schwannom og en } \\
\text { førstegradsslektning som oppfyller kriteriene for } \\
\text { sikker schwannomatose }\end{array}$ \\
\hline \multirow{2}{*}{$\begin{array}{l}\text { Segmental } \\
\text { schwannomatose }\end{array}$} & A & $\begin{array}{l}\text { Oppfyller kriteriene for sikker eller mulig } \\
\text { schwannomatose, men begrenset til én } \\
\text { ekstremitet eller fem eller færre påfølgende } \\
\text { spinale nivåer }\end{array}$ \\
\hline
\end{tabular}

'Nevrofibromatose type 2 er usannsynlig hos en person som er > 45 år og som ikke har symptomer pá affeksjon av 8 . hjernenerve 


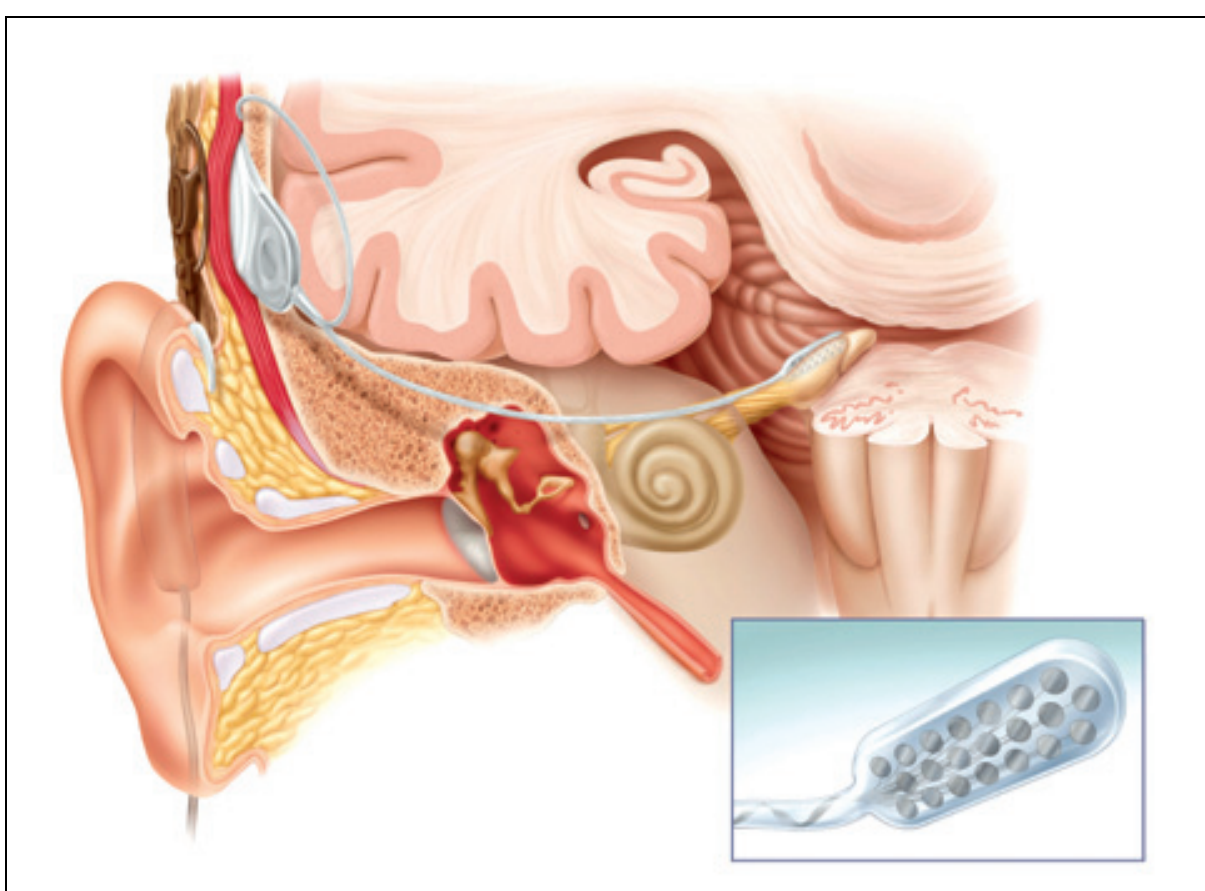

Figur 5 Figuren viser et auditorisk hjernestammeimplantat med en ekstern mikrofon festet bak øret, en subkutan mottakerenhet og en elektrodeplate festet på overflaten av hjernestammen ved cochleariskjernene. I nedre høyre hjørne vises elektrodeplaten, som her har 21 elektroder, med større forstørrelse. Gjengitt med tillatelse fra Cochlear Nordic $A B$

mene er en viktig del av behandlingen. Vestibularisschwannomene ved nevrofibromatose type 2 er vanskeligere å behandle enn sporadiske vestibularisschwannomer (9). Ofte omslutter vestibularisschwannomene ved nevrofibromatose type 2 den 8 . hjernenerve og hyppig ses flere svulster. Vanligvis tapes hørselen etter kirurgisk behandling, og perifer facialisparese er en fryktet komplikasjon. Valg av behandlingstype og tidspunkt for behandling må tilpasses det enkelte tilfellet. Ved små vestibularisschwannomer kan hørselsbevarende kirurgi forsøkes. Selv om hørselen likevel tapes etter inngrepet, vil hørselsnerven i enkelte tilfeller være delvis intakt. Da vil noen pasienter kunne gjenvinne hørsel med et cochleaimplantat (18). Ved større, asymptomatiske svulster velges som regel konservativ behandling (9). Kirurgisk behandling vil være indisert når hørselen er tapt, ved affeksjon av 5. og 7. hjernenerve, ved kompresjon av hjernestammen og ved forhøyet intrakranialt trykk.

Behandling av vestibularisschwannomer ved nevrofibromatose type 2 med stereotaktisk strålekirurgi har vært assosiert med økt risiko for utvikling av ondartede svulster (19). Derfor har denne behandlingsformen hovedsakelig vært brukt når det foreligger kontraindikasjoner mot kirurgi eller om pasienten selv ikke ønsker kirurgisk behandling. Nyere forskning tyder imidlertid på at risikoen for stråleindusert utvikling av ondartede svulster er lavere enn tidligere antatt og at behandlingsresultatene er relativt gode $(20,21)$. Dermed kan stereotaktisk strålekirurgi være et alternativ til kirurgisk behandling hos flere av pasientene.

\section{Auditorisk hjernestammeimplantat}

Hørselsrehabilitering er en viktig del av behandlingen. Ved nevrofibromatose type $2 \mathrm{er}$ hørselsnerven ofte destruert, og i slike tilfeller har et cochleaimplantat ingen funksjon. Derimot kan direkte stimulering av de sentrale hørselsbanene i hjernestammen ved innsetting av et auditorisk hjernestammeimplantat gi deler av hørselen tilbake.

Ved auditorisk hjernestammestimulering tas et akustisk signal imot av en ekstern mikrofon festet bak øret, som vist i figur 5. Signalet bearbeides i en prosessor før det sendes som et radiosignal til en subkutan mottakerenhet. Herfra overføres informasjonen til en elektrodeplate med inntil 21 elektroder festet på overflaten av hjernestammen ved cochleariskjernene (22). Ved elektrisk stimulering aktiveres de sentrale hørselsbanene. 6-8 uker etter implantasjonen kartlegger man hvilke elektroder som kan benyttes, samtidig som man utfører den første programmeringen av apparatet. Uønsket stimulering av naboområder i hjernestammen er vanlig og kan gi bivirkninger som parestesier og svimmelhet. Dette kan føre til at enkelte elektroder må inaktiveres (22).

Gjentatte programmeringer av apparatet vil bli nødvendig og innlæringsprosessen er langvarig. Bedringen av hørsel fortsetter hos mange i opptil ti år etter implantasjonen (23). Graden av hørsel som oppnås etter behandlingen er varierende, avhenger av antall fungerende elektroder og er generelt dårligere enn ved behandling med et cochleaimplantat $(22,23)$. Imidlertid vil gjenvinning av en viss hørsel ha stor funksjonell og psykologisk betydning for mange. Hos de fleste bedres evnen til munnavlesning og kvaliteten på egen tale. Majoriteten kan nyttiggjøre seg lyder fra omgivelsene. Derimot vil som regel taleoppfattelse uten munnavlesing være begrenset (23). Det er nylig publisert resultater fra forsøk på å stimulere hørselsbanene gjennom elektroder som penetrerer hjernestammen i tillegg til stimulering via elektrodeplaten på overflaten. Imidlertid er resultatene foreløpig ikke bedre enn ved stimulering med elektrodeplaten alene (24).

I dag er døvhet ved nevrofibromatose type 2 den hyppigste indikasjonen for auditorisk hjernestammestimulering. Behandlingen har også vært benyttet ved bilateral avrivning av hørselsnerven etter skallefraktur, hos barn med misdannelser og ved forkalkninger i det indre øret etter meningitt (22).

\section{Avslutning}

Nevrofibromatose type 2 er en alvorlig, invalidiserende sykdom som krever tverrfaglig og sentralisert behandling. Avgjørelsen om når og på hvilken måte svulstene skal behandles, kan være vanskelig og bør tas av erfarne behandlere. Ved døvhet kan et auditorisk hjernestammeimplantat gi deler av hørselen tilbake. Dette kan ha stor funksjonell og psykologisk betydning.

Det er et klart behov for nye behandlingsformer ved sykdommen. Økt kunnskap om tumorsuppressorproteinet merlins funksjon kan muliggjøre fremtidig molekylært rettet terapi. Angrepspunkter for slik behandling kan være reseptortyrosinkinaser og intracellulære signalveier som regulerer celleproliferasjon og cellevekst. I en nylig publisert kasuistikk beskrev man behandling av en person med nevrofibromatose type 2 med en lavmolekylær tyrosinkinaseinhibitor (erlotinib) (25). Slik behandling reduserte størrelsen på et vestibularisschwannom og bedret hørselen. Videre undersøkes i pågående fase 2-studier effekten av en reseptortyrosinkinasehemmer (sunitinib) hos personer med residiverende meningeomer og ikke-operable meningeomer ( $w w w . c l i n i c a l t r i a l s . g o v:$ NCT00561665 og NCT00589784). Her vil også personer med nevrofibromatose type 2 kunne rekrutteres. Samlet gir dette håp om bedret fremtidig behandling for denne pasientgruppen.

Oppgitte interessekonflikter: Ingen

\section{Litteratur}

1. Ferner RE. Neurofibromatosis 1 and neurofibromatosis 2: a twenty first century perspective. Lancet Neurol 2007; 6: 340-51.

2. Evans DG, Moran A, King A et al. Incidence of vestibular schwannoma and neurofibromatosis 2 in the North West of England over a 10-year period: higher incidence than previously thought. Otol Neurotol 2005; 26: 93-7

3. Evans DG, Huson SM, Donnai D et al. A clinical study of type 2 neurofibromatosis. Q J Med 1992; 84: $603-18$

4. Evans DG, Sainio M, Baser ME. Neurofibromatosis type 2. J Med Genet 2000; 37: 897-904.

5. Ruggieri M, Huson SM. The clinical and diagnostic implications of mosaicism in the neurofibromatoses. Neurology 2001; 56: 1433-43. 
6. Moyhuddin A, Baser ME, Watson C et al. Somatic mosaicism in neurofibromatosis 2: prevalence and risk of disease transmission to offspring. J Med Genet 2003; 40: 459-63.

7. McClatchey Al, Giovannini M. Membrane organization and tumorigenesis - the NF2 tumor suppressor, Merlin. Genes Dev 2005; 19: 2265-77.

8. McClatchey Al. Neurofibromatosis. Annu Rev Pathol 2007; 2: 191-216.

9. Evans DG, Baser ME, O'Reilly B et al. Management of the patient and family with neurofibromatosis 2: a consensus conference statement. Br J Neurosurg 2005; 19: 5-12

10. Evans DG, Birch JM, Ramsden RT. Paediatric presentation of type 2 neurofibromatosis. Arch Dis Child 1999; 81: 496-9

11. MacCollin M, Mautner VF. The diagnosis and management of neurofibromatosis 2 in childhood. Semin Pediatr Neurol 1998; 5: 243-52.

12. Bosch MM, Boltshauser E, Harpes P et al. Ophthalmologic findings and long-term course in patients with neurofibromatosis type 2. Am J Ophthalmol 2006; 141: 1068-77.

13. Sperfeld AD, Hein C, Schroder JM et al. Occurrence and characterization of peripheral nerve involvement in neurofibromatosis type 2 . Brain 2002; 125: $996-1004$

14. Baser ME, Friedman JM, Wallace AJ et al. Evaluation of clinical diagnostic criteria for neurofibromatosis 2. Neurology 2002; 59: 1759-65.

15. Hanemann CO. Magic but treatable? Tumours due to loss of merlin. Brain 2008; 131: 606-15.

16. MacCollin M, Chiocca EA, Evans DG et al. Diagnostic criteria for schwannomatosis. Neurology 2005; 64: 1838-45

17. Baser ME, Evans DG, Gutmann DH. Neurofibromatosis 2. Curr Opin Neurol 2003; 16: 27-33.

18. Neff BA, Wiet RM, Lasak JM et al. Cochlear implantation in the neurofibromatosis type 2 patient: long-term follow-up. Laryngoscope 2007; 117: 1069-72.

19. Baser ME, Evans DG, Jackler RK et al. Neurofibromatosis 2, radiosurgery and malignant nervous system tumours. Br J Cancer 2000; 82: 998.

20. Mathieu D, Kondziolka D, Flickinger JC et al. Stereotactic radiosurgery for vestibular schwannomas in patients with neurofibromatosis type 2 an analysis of tumor control, complications, and hearing preservation rates. Neurosurgery 2007. 60: $460-8$

21. Rowe J, Grainger A, Walton L et al. Safety of radiosurgery applied to conditions with abnormal tumor suppressor genes. Neurosurgery 2007; 60: 860-4.

22. Nyberg G, Kinnefors A, Gudjonson 0 et al. Hjärnstamsimplantat kan återge hørsel. Behandling av dövhet vid dubbelsidiga akustikusneurinom. Läkartidningen 2007; 104: 3553-6.

23. Schwartz MS, Otto SR, Shannon RV et al. Auditory brainstem implants. Neurotherapeutics 2008; 5 . 128-36.

24. McCreery DB. Cochlear nucleus auditory prostheses. Hear Res 2008; 242: 64-73.

25. Plotkin SR, Singh MA, O'Donnell CC et al. Audio logic and radiographic response of NF2-related vestibular schwannoma to erlotinib therapy. Nat Clin Pract Oncol 2008; 5: 487-91.

Manuskriptet ble mottatt 19.8. 2008 og godkjent 23.4. 2009. Medisinsk redaktør Åslaug Helland. 